\title{
Transitional crust-mantle geodynamics recorded by Late Archean ( 3.0-2.5 Ga) multiple K-rich granitoids of North China Craton
}

\author{
WEI WANG ${ }^{1}$ AND SHUWEN LIU ${ }^{2}$
}

${ }^{1}$ School of Earth Sciences and Resources, China University of Geosciences, Beijing 100083, PR China

${ }^{2}$ School of Earth and Space Sciences, Peking University, Beijing 100871, PR China

Lithological assemblages, chronological data, and petrochemical features of multiple late Archean K-rich granitoid rocks ( 3.0-2.9, $\sim 2.7$, and $\sim 2.6-2.4 \mathrm{Ga}$ (mostly $\sim 2.53-2.47 \mathrm{Ga}$ )) from North China Craton are reviewed to unravel the crust-mantle geodynamic origin of late Archean K-rich granitoid magmatism.

The Mesoarchean granitic gneisses of Anshan-Benxi are strongly peraluminous with muscovite and tourmaline. They show low $\mathrm{CaO} / \mathrm{Na}_{2} \mathrm{O}, \mathrm{Al}_{2} \mathrm{O}_{3} / \mathrm{TiO}_{2}, \Delta \mathrm{Sr}$, and $(\mathrm{La} / \mathrm{Yb})_{\mathrm{N}}$, and negative zircon $\mathrm{EHf}(\mathrm{t})$ that formed by high-T-low-P melting of metapelites. Linear zircon $\mathrm{EHf}(\mathrm{t})$-age array of $\sim 3.8-2.9$ Ga felsic rocks implies sluggish crust-mantle interactions under a stagnant-lid setting.

Early Neoarchean K-rich granitoids occur in Jiaobei and southern North China Craton. The quartz monzodioritic to granodioritic rocks show moderate $\mathrm{FeO}_{\mathrm{T}}+\mathrm{MgO}$ but high $\mathrm{Mg} \#$. They contain euhedral muscovite with peraluminous features and mildly depleted zircon $\mathrm{EHf}(\mathrm{t})$, indicating hydrous mantle sources with recycled sediment melts. The monzo-/syenogranitic rocks have mildly depleted to negative zircon $\mathrm{EHf}(\mathrm{t})$, high $\mathrm{CaO} / \mathrm{Na}_{2} \mathrm{O}$ and $\mathrm{Al}_{2} \mathrm{O}_{3} / \mathrm{TiO}_{2}$, and moderate $\Delta \mathrm{Sr}$ and $(\mathrm{La} / \mathrm{Yb})_{\mathrm{N}}$, suggesting highP-low-T melting of clay-poor sedimentary rocks. Moderate crustmantle interactions and melt-dominated mantle metasomatism are linked to hot subduction and arc-continent accretion processes.

Late Neoarchean K-rich granitoids are ubiquitous across the craton. The intermediate rocks show high $\mathrm{FeO}_{\mathrm{T}}+\mathrm{MgO}$ and $\mathrm{Mg}$ \#. Chemical modeling, coupled with low $\mathrm{Nb} / \mathrm{Th}$ and $\mathrm{TiO}_{2} / \mathrm{Yb}$, high $\mathrm{La} / \mathrm{Yb}$ and $\mathrm{Nb} / \mathrm{Yb}$, and positive correlation of $(\mathrm{Hf} / \mathrm{Sm})_{\mathrm{N}}$ and $(\mathrm{Nb} / \mathrm{La})_{\mathrm{N}}$, indicate derivation from variably enriched mantle sources metasomatized by fluids. The acidic rocks have varied $\mathrm{CaO} / \mathrm{Na}_{2} \mathrm{O}, \mathrm{A} / \mathrm{CNK}$, and normalized REE patterns, and depleted to strongly enriched zircon $\mathrm{EHf}(\mathrm{t})$. These data suggest complex crustal sources at diverse crustal levels with mantle inputs. Given vigorous crust-mantle interactions, fluid-dominated mantle metasomatism, and peaked sediment involvement and crustal thickness at $2530-2480 \mathrm{Ma}$, late Neoarchean granitoid magmatism occurred possibly at Phanerozoic-like plate tectonics. In summary, the above late Archean K-rich granitoid magmatism record transition from stagnant-lid to gradually stabilized plate tectonics. The crust-mantle interactions enhanced stepwise, and exerted a first-order control on the increasing lithological and chemical diversification of the K-rich granitoids. 